\title{
PARA COMPREENDER O MUNDO DO TRABALHO
}

A discussão do mundo de trabalho hoje ganha relevância tanto pela crise global e do emprego quanto, principalmente, pela centralidade que a categoria trabalho tem na vida e no desenvolvimento das pessoas no contexto do capitalismo contemporâneo. Salários, preços e lucros entram em contradição marcadamente diante das crises capitalistas e da tendência às taxas decrescentes de lucros, implicando redução do preço dos salários. Estudioso do tema do trabalho e das relações de trabalho e sindicais, o Prof. Dr. Arnaldo Jose Franca Mazzei Nogueira, da PUC-SP e da USP, selecionou obras que refletem, critica e objetivamente, sobre as consequências sociais e políticas das atuais formas de produção do valor na esfera produtiva.
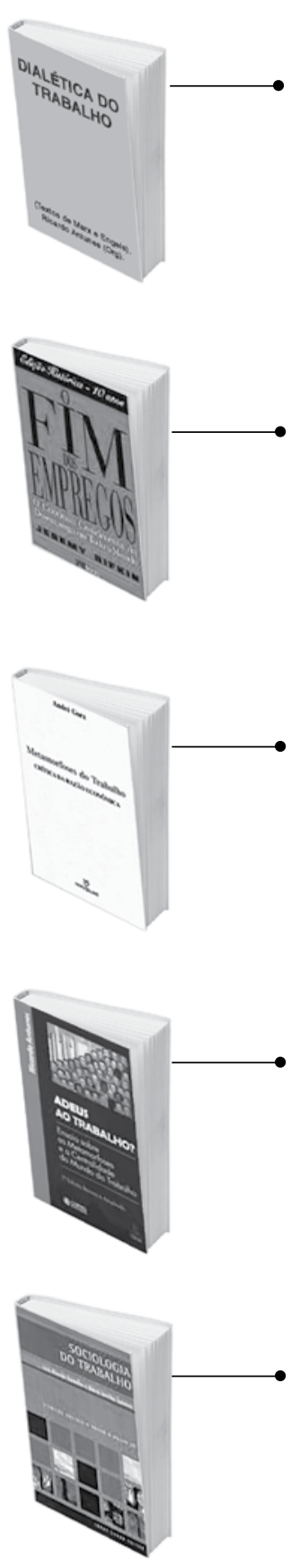

DIALÉtICA DO TRABALHO (TEXTOS DE MARX E ENGELS). Ricardo Antunes (Org). São Paulo: Expressão Popular, 2004.

Nessa obra, Ricardo Antunes seleciona textos de Karl Marx e Friedrich Engels que envolvem uma discussão crítica das atuais condições e do futuro do trabalho, alimentando a utopia da transformação social em contraponto às tentativas de negociação da crise nos marcos do capitalismo, que apenas legitimam e prorrogam o descarte do trabalho em massa, principalmente em momentos de crise sistêmica como os atuais.

O FIM DOS EMPREGOS. Jeremy Rifkin. São Paulo: M. Books, 2004. 340 p.

Essa obra é recomendável, pois, por um lado, analisa as mudanças tecnológicas e as reestruturações organizacionais que levariam ao fim do emprego estável e regular. Por outro, devido ao fato de o objeto de sua investigação serem exatamente os Estados Unidos, epicentro da atual crise. Aqui, o autor aponta a artificialidade de uma economia orientada pelo esquema financeiro e sustentada pelo crédito fácil em oposição à lógica destrutiva da força de trabalho, que exige um novo, e frágil, contrato social via terceiro setor.

METAMORFOSES DO TRABALHO: Crítica da razão econômica. André Gorz. São Paulo: Anablume, 2003. 247 p.

$\mathrm{O}$ autor critica toda a racionalidade irracional da modernidade orientada pela razão econômica que desloca o trabalho do centro das economias via terceirização. Assim, a verdadeira crise é da utopia, pois o desenvolvimento das forças produtivas e a expansão da esfera econômica não liberaram a humanidade da penúria, da injustiça e do mal-estar. A nova utopia cria uma ilusão de sentido para o trabalho, ao anunciar a possibilidade de sua autonomia a partir da polivalência, da alta qualificação e da autoorganização da força de trabalho.

ADEUS AO TRABALHO? ensaio sobre as metamorfoses e a centralidade do trabalho. Ricardo Antunes. São Paulo: Cortez, 2008. 213 p.

A interrogação do título não é à toa. Contrariamente, às teses do fim da centralidade do trabalho, o autor fundamentado na teoria do valor-trabalho formulada por Karl Marx, defende sua absoluta importância no entendimento das transformações atuais conduzidas pelo capital e que levam à manipulação, transformação e destruição do trabalho. Para Antunes, apenas pelo trabalho e pela união de todo o proletariado moderno em um projeto econômico alternativo e político é possível forjar transformações práticas e de sentido mais substantivas no sentido do socialismo.

SOCIOLOGIA DO TRABALHO NO MUNDO CONTEMPORÂNEO. José Ricardo Ramalho e Marco Aurélio Santana. Rio de Janeiro: Jorge Zahar, 2004.

Essa obra aborda questões relevantes da sociologia do trabalho, tais como: mudanças tecnológicas, gestão, qualificação dos trabalhadores, flexibilidade e presença da força de trabalho da mulher, que traz novos desafios à pesquisa. Problematiza, ainda, o papel dos sindicatos num contexto de políticas neoliberais do Estado mínimo e de crenças no mercado. Questiona, também, se a sociedade atual será capaz de formular novos direitos inclusivos ou se continuará acelerando o passo em direção a novas desigualdades e aumento da exclusão. 